\title{
The Revival of Translation as a Fifth Skill in the Foreign Language Classroom: A Review of Literature
}

\author{
Houda AYACHIA \\ Department of English \\ Faculty of Letters and Languages \\ University Mentouri Bro. Constantine 01, Algeria
}

\begin{abstract}
With the advent of the monolingual principle entrenched by the Reform Movement of the late nineteenth century and exponents of the Direct Method, translation has been treated, for a long time, as a skeleton in the closet. Recently, however, many researchers (Witte, Harden \& Ramos de Oliveira Harden, 2009; Cook, 2010; Leonardi, 2010; Malmkjaer, 2010) have questioned the outright dismissal of translation from the foreign language classroom and called for reassessing its role. Moreover, they welcomed it as a fifth skill alongside reading, writing, listening, and speaking that learners need in their learning and future careers. This paper argues for the rehabilitation of translation in the teaching and learning of foreign languages. It attempts to give a panorama of the revival of translation. So, it first reconsiders its dismissal in the method era and then it summarises the literature on its revival in the $21^{\text {st }}$ century. The review of literature has revealed that the onslaught against translation was illegitimate and that the literature in favour of it is a reputable, a recent, and an abundant one.
\end{abstract}

Keywords: fifth skill, foreign language classroom, the revival, translation

Cite as: AYACHIA, H. (2018). The Revival of Translation as a Fifth Skill in the Foreign Language Classroom: A Review of Literature. Arab World English Journal for Translation \& Literary Studies, 2 (2). DOI: http://dx.doi.org/10.24093/awejtls/vol2no2.13 